Süğümlü, Ü. ve Eraslan, A. (2019). Ortaokul Türkçe ders kitaplarında yer alan metin türleri ile kalıplaşmış söz varlığı ilişkisi. Ana Dili Eğitimi Dergisi, 7(3), 630-646.

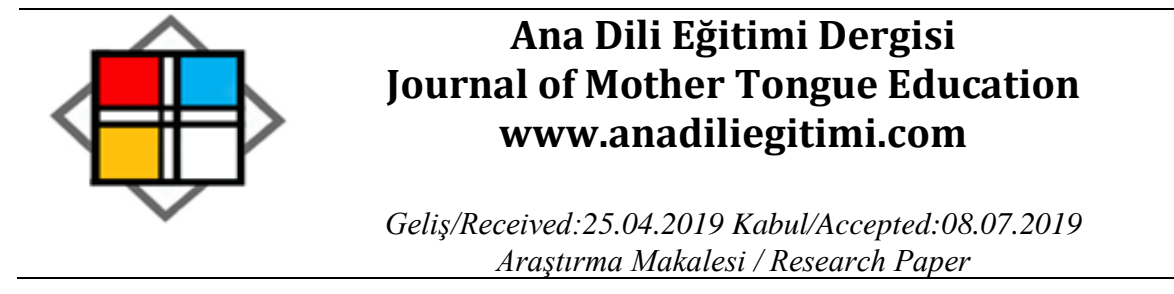

\title{
Ortaokul Türkçe Ders Kitaplarında Yer Alan Metin Türleri ile Kalıplaşmış Söz Varlığı ilişkisi*
}

\author{
Üzeyir SÜĞÜMLÜ** \\ Asena ERASLAN ${ }^{* * *}$
}

\begin{abstract}
Öz
Araştırmanın amacı, Türkçe Dersi Öğretim Programı (2018) temelinde hazırlanmış ortaokul Türkçe ders kitaplarında (MEB Yayınları) yer alan metin türleri ile kalıplaşmış söz varlığı ilişkisini belirlemektir. Türkçe dersi, metinler üzerinden gerçekleştirilen bir derstir. Metinlerdeki kalıplaşmış söz varlığı unsurlarını belirlemek, metin türleriyle kalıplaşmış söz varlığı unsurları arasındaki ilişkiyi ortaya çıkarmak, araştırma için önemli görülmektedir. Araştırma, nitel bir araştırma özelliği taşımaktadır ve temel nitel araştırma ile gerçekleştirilmiştir. Araştırmanın verilerini 5, 6, 7 ve 8 . sınıf Türkçe ders kitaplarında yer alan 95 metin oluşturmuştur. Araştırma verilerinin toplanması, doküman incelemesi ile gerçekleştirilmiştir. Metinler türlerine göre sınıflandırılmış ve metinlerdeki kalıplaşmış söz varlığı unsurları belirlenmiştir. Araştırmanın verileri, betimsel analiz tekniğiyle çözümlenmiştir. Metin türleri ile kalıplaşmış söz varlığı unsurları arasındaki ilişki, tablolarla gösterilmiş ve yorumlanmıştır. Araştırma ile şu sonuçlara ulaşılmıştır: Kalıplaşmış söz varlığı unsurlarının en fazla yer aldığı metin türünün öykü olduğu, metin türlerinde en fazla kalıplaşmış söz varlığı unsurlarından deyimlere yer verildiği, en az yer verilen kalıplaşmış söz varlığı unsurunun ise atasözü olduğu belirlenmiştir.
\end{abstract}

Anahtar Kelimeler: ders kitabı, metin, metin türü, kalıplaşmış söz varlığı.

\section{Relationship Between Text Types and Formulaic Expression in Secondary School Turkish language Arts Textbooks}

\begin{abstract}
The aim of this study was to determine the relationship between text types and formulaic expression in secondary school Turkish textbooks (MoNE Publications) prepared based on the Turkish Language Arts Curriculum (2018). Turkish is a lesson carried out by using texts. The present study placed importance on determining the elements of formulaic expression in the texts and to reveal the relation between text types and elements of formulaic expression. The present study employed the qualitative research method for data collection. Data was collected from 95 texts from 5th, 6th, 7th and 8th grade Turkish language arts textbooks. The collection of data was completed with document review. The texts were classified according to type and the elements of formulaic expression in the texts were determined. The data were determined with the descriptive analysis technique. The relationship between text types and elements of formulaic expression was shown with tables and assessed accordingly. This study concluded the following results: The text type with the most elements of formulaic expression are stories, idioms are the most commonly
\end{abstract}

\footnotetext{
* Bu araştırma, 25-28 Nisan 2019 tarihlerinde Rize'de düzenlenen XII. Uluslararası Eğitim Araştırmaları Kongresi'nde sunulan sözlü bildirinin genişletilmiş hâlidir.

** Dr. Öğr. Üyesi, Ordu Üniversitesi, Eğitim Fakültesi, Türkçe ve Sosyal Bilimler Eğitimi Bölümü, Türkçe Eğitimi Ana Bilim Dalı, Ordu, u.sugumlu@gmail.com, ORCID: 0000-0003-2135-5399

*** Yüksek Lisans Öğrencisi, Ordu Üniversitesi, Sosyal Bilimler Enstitüsü, Türkçe Eğitimi Ana Bilim Dalı, Ordu, asenaecrin69@gmail.com, ORCID: 0000-0002-6621-9457
} 
used formulaic expression in text types and proverbs determined are the element of formulaic expression used the least.

Keywords: textbooks, text, text type, formulaic expression.

\section{Giriş}

Dil; duygu, düşünce ve isteklerin çeşitli kurallar doğrultusunda başkalarına aktarılmasını sağlayan çok yönlü bir bildirim aracı olarak tanımlanabilir. Dilin sunduğu anlama ve anlatma imkânlarından faydalanabilmek ve kültürel mirastan pay alabilmek için o dilin söz varlığına ve kurallarına hâkim olmak gerekir (Demir, 2016).

Söz varlığı, bir dildeki sözlerin bütünü, söz hazinesi, söz dağarcığı, vokabüler, kelime hazinesi (TDK, 2005) olarak tanımlanmaktadır. Aksan'a (2004) göre bir dilin söz varlığı, o dilin tarihine geniş ölçüde ışık tutmakta, yüzyıllar boyunca ortaya çıkan ses, biçim, söz dizimi ve anlam değişikliklerini yansıtmakta, hangi dillerin etkisiyle, ne türden değişimlerin gerçekleştiğini göstermektedir. Bir dilin söz varlığından kastedilen o dile ait sözcükler, deyimler, terimler, atasözleri, kalıplaşmış sözler, mecazlar ve yan anlamlar gibi güçlü ve zengin bir kavram dünyasıdır (Karadüz, 2009). Bu kavramların öğretimi, büyük oranda eğitim ortamlarında gerçekleştirilmektedir. Dil edinme süreci doğal ortamda başlamış olsa da okullarda okutulan edebi metinler ve derslerde yapılan öğretim etkinliklerinin de dili etkin kullanabilme becerilerini geliştirmede payı oldukça fazladır (Karatay, 2016).

Etkin bir söz varlığı kazanımı, öğrencilerin kelimeleri, ilgili kavramları ve anlamlarını öğrenmesi için eğitimcilerin öğrencilerine planlı bir biçimde hareket ederek geniş ve yeterli imkânlar sağlamasını gerektirir (Esgin, 2016). Hedeflenen kazanımın ulaşılabilirliği, süreç içerisinde öğrencilere okutulacak metinlerin içerdiği söz varlığı unsurların yeterliğiyle doğrudan ilişkilidir. Çünkü eğitim sürecinde özellikle ülke şartları göz önüne alındığında ders kitapları eğitimin en önemli destekçisi durumundadır. Dolayısıyla söz varlığının geliştirilmesi hususunda en büyük payda öğrencilere okutulacak metinlere düşmektedir. Demir'e (2016) göre yaş gruplarına veya eğitim-öğretim kademelerine göre belirlenmiş temel söz varlığını esas alarak yazılan kitaplar ve diğer dokümanlar, hem okuma eğitiminde hem de söz varlığını geliştirmede kullanılabilecek ideal materyallerdir. Bu materyaller yoluyla zenginleşen söz varlığı da öğrencilerin okudukları metinlerin anlamsal yapısını fark etmeleri, bu farkındalıkla beraber dili etkin kullanabilmeleri açısından önemlidir. Göçer'in (2009) "Okul hayatında öğrencilerin hem okudukları metinleri, dinledikleri konuşmaları tam ve doğru bir şekilde anlamaları hem de anladıklarıyla ilgili düşüncelerini anlatabilmeleri için kelime dağarcığının önemi büyüktür" ifadesi de bunu destekler niteliktedir.

Özellikle Türkçe dersleri, söz varlığının metinler aracılığıyla geliştirilmesini sağlayan en uygun derslerdendir. Türkçe derslerinin temel amaçlarından biri, öğrencilerin hem okul hayatında başarılı olmalarını sağlayacak hem de sosyal hayatta ihtiyaç duyacakları dil becerilerini zenginleştirecek bir söz 
varlığını onlara kazandırmaktır. Çünkü öğrencilerin dil becerileri sahip oldukları söz varlı̆ından büyük ölçüde etkilenmektedir (Tağa, 2016). Öngörülen amaç doğrultusunda metinlerdeki söz varlığı unsurlarının niceliğinin belli bir olgunluğa ulaştırılması gerekliliği görülmektedir. Başka dillerle karşılaştırıldığı zaman Türkçenin söz varlığında daha çok kalıplaşmış dil birimi yani atasözü, deyim, ikileme ve kalıp söz bulunmaktadır (Gökdayı, 2008).

Dilin söz varlığı, insan düşünce ve duygularının derinliğinden çıkmış toplumsal etkileşiminin varlığı olarak değerini korumuş bir öze sahiptir (Karadüz, 2009). Bu öz dilimizde oldukça baskın şekildedir. Bunun nedeni Türkçenin geniş anlatım imkanlarıyla donanmış, zengin söz varlığına sahip bir dil olmasıdır. Kelime dağarcığını geliştirmek, Türkçe dersinin amaçları arasında yer aldığı için etkin bir söz varlığının edinimi de büyük oranda Türkçe derslerine bağlanmaktadır. Metinlerde söz varlığı unsurlarına yeterli düzeyde yer verilmesi hem öğrencilerde dil bilinci oluşmasını hem de öğrencilerin duygu ve düşünce dünyalarının zenginleşmesini sağlayacaktır. Bu araştırma ile Türkçe ders kitabında yer alan metinler, türlerine göre sınıflandırılarak hangi metin türünde hangi kalıplaşmış söz varlığı unsurlarına ne derece yer verildiği belirlenmiştir. Bu durum ise, dersin hedeflediği kazanımlar için temel koşullardan biri olan söz varlı̆̆ı unsurlarının, metinlerde belli bir olgunluğa ulaştırıması gerekliliğine dayanak olacaktır. Metin türleri ile kalıplaşmış söz varlığı unsurları arasındaki ilişkiye yönelik alanyazında herhangi bir çalışmaya rastlanmamıştır. Bu nedenle, araştırmanın Türkçe ders kitaplarında yer alan metin türleri ile kalıplaşmış söz varlığı unsurları arasındaki ilişkinin belirlenerek metin türleri temelinde kalıplaşmış söz varlığı unsurlarının öğretimine katkı sağlayacağı düşünülmektedir.

Bu araştırmanın amacı, Türkçe Dersi Öğretim Programı (2018) temelinde hazırlanmış ortaokul Türkçe ders kitaplarında yer alan metin türleriyle bu metinlerde kullanılan kalıplaşmış söz varlı̆ı̆ unsurları arasındaki ilişkiyi belirlemektir. Bu amaç doğrultusunda aşağıdaki araştırma sorularına cevap aranmıştır:

1. 5. Sınıf Türkçe Ders Kitabı'nda hangi tür metinler yer almaktadır ve kalıplaşmış söz varlığı unsurları, hangi metin türünde yoğun olarak bulunmaktadır?

2. 6. Sınıf Türkçe Ders Kitabı'nda hangi tür metinler yer almaktadır ve kalıplaşmış söz varlığı unsurları, hangi metin türünde yoğun olarak bulunmaktadır?

3. 7. Sınıf Türkçe Ders Kitabı́nda hangi tür metinler yer almaktadır ve kalıplaşmış söz varlı̆̆ı unsurları, hangi metin türünde yoğun olarak bulunmaktadır?

4. 8. Sınıf Türkçe Ders Kitabı'nda hangi tür metinler yer almaktadır ve kalıplaşmış söz varlı̆̆ı unsurları, hangi metin türünde yoğun olarak bulunmaktadır?

5. Ortaokul Türkçe ders kitaplarında, en çok kullanılan metin türleri hangileridir ve bu metin türlerinde hangi kalıplaşmış söz varlığı unsurları daha yoğun bulunmaktadır?

6. Ortaokul Türkçe ders kitaplarında, en az fazla ve en az yer verilen kalıplaşmış söz varlı̆̆ı unsurları hangileridir? 


\section{Yöntem}

\section{Araştırmanın Modeli}

Araştırma, nitel araştırma özelliği taşımaktadır ve temel nitel araştırma ile gerçekleştirilmiştir. Temel nitel araştırma, tüm disiplin alanlarında ve pratikte uygulama alanlarında görülebilen, eğitimde kullanılabilen en yaygın nitel araştırma biçimlerindedir. Bu araştırma türünde veriler; gözlem, görüşsme ya da doküman incelemesi yoluyla toplanır (Merriam, 2013). Araştırma, eğitimde kullanılan ders kitapları üzerine gerçekleştirilmiş ve araştırmanın verileri, doküman incelemesi yoluyla toplanmıştır.

\section{Çalışma Materyali}

Araştırmanın verilerini belirlemek için 2018-2019 eğitim-öğretim yılında MEB tarafından okutulmasına karar verilen Türkçe ders kitapları belirlenmiştir. 5 Türkçe öğretmeni ve 3 alan uzmanının görüşleri doğrultusunda bu kitaplar arasından MEB'in kendi hazırladığı ve elektronik olarak da erişime açtığı Türkçe Ders Kitapları seçilmiş̧ir. Araştırmanın verilerini; Ortaokul 5, 6, 7 ve 8. sınıf Türkçe ders kitaplarında (MEB Yayınları) yer alan 95 metin (belge) oluşturmaktadır. Dinleme/izleme, serbest okuma ve görsel metinler (yazı içerenler hariç) araştırma verileri kapsamına alınmamıştır. Programda belirtilen blog türü metinler, içerikleri dikkate alınarak (nesnel bir anlatımın olması ve bilgilendirmeye yönelik bir içeriğe sahip olması) dayalı makale türü kapsamında değerlendirilmiştir.

\section{Veri Toplama Araçları ve Verilerin Toplanması}

Araştırmanın veri toplama araçlarını; Türkçe Dersi Öğretim Programı'nda (2018) yer alan kalıplaşmış söz varlığı unsurlarına ilişkin kazanımlar, programda yer alan metin türleri tablosu ve Türk Dil Kurumunun Genel Ağ adresinde yer alan “Güncel Türkçe Sözlük” ve “Atasözleri ve Deyimler sözlüğü” oluşturmaktadır. Araştırma verilerinin toplanması, doküman incelemesi ile gerçekleştirilmiştir. Dokümanlar, nitel araştırmalarda etkili bir şekilde kullanılması gereken önemli bilgi kaynaklarıdır (Yıldırım ve Şimşek, 2013). Var olan kayıt ve belgeleri inceleyerek veri toplamaya belgesel (doküman incelemesi) tarama denir ve bu belli bir amaca dönük olarak, kaynakları bulma, okuma, not alma ve değerlendirme işlemlerini kapsar (Karasar, 2012). Çalışmanın verileri olan Türkçe ders kitaplarında yer alan 95 metin incelenmiştir. Incelenen metinler, programda yer alan metin türleri tablosuna göre sınıflandırılmıştır. Programda yer alan kalıplaşmış söz varlığı unsurlarına ilişkin kazanımlar belirlenmiştir (atasözü, deyim, ikileme ve kalıplaşmış ifade). Metinlerde yer alan kalıplaşmış söz varlığı unsurları, Türk Dil Kurumunun Genel Ağ adresinde yer alan "Güncel Türkçe Sözlük" ve "Atasözleri ve Deyimler Sözlüğü" kullanılarak belirlenmiştir.

\section{Verilerin Analizi}

Veri analizi, verinin anlamını dışarıya aktarma sürecidir. Verinin anlamını dışarıya aktarma; insanların ne söylediğini, araştırmacının ne gördüğünü ve okuduğunu birleştirme, indirgeme ve 


\section{Ortaokul Türkçe Ders Kitaplarında Yer Alan Metin Türleri ile Kalıplaşmış Söz Varlığı iliş̧kisi}

yorumlamayı içerir (Merriam, 2013). Araştırmanın verileri, betimsel analiz tekniği ile çözümlenmiştir. Betimsel analiz yaklaşımında elde edilen veriler, daha önceden belirlenen temalara göre özetlenir ve yorumlanır (Yıldırım ve Şimşek, 2013). Önce ders kitaplarındaki temalarda yer alan metinler ve türleri ile bu metinlerde yer alan kalıplaşmış söz varlığı unsurları belirlenmiştir. Sonra her sınıf düzeyi için metin türleri ve sayısı ile metin türlerinde yer alan kalıplaşmış söz varlığı unsurları ve sayısını gösteren tablolar oluşturulmuştur. Metin türleri ve kalıplaşmış söz varlığı unsurları ilişkilendirilerek çalışmanın bulgularına ulaşılmıştır.

\section{Bulgular}

\section{Sınıf Türkçe Ders Kitabı'nda Yer Alan Metin Türleri ve Kalıplaşmış Söz Varlığı Unsurları}

"Çocuk Dünyası" temasında 2 metin öykü ve 1 metin şiirdir. "Oyuncak" başlıklı öyküde 6 deyim, 4 ikileme, 1 kalıplaşmış ifade yer almış, atasözü yer almamıştır. "Çocukluk" başlıklı şiirde deyim, atasözü ve kalıplaşmış ifade yer almamış, yalnızca 2 ikileme yer almıştır. "Ben Bir Çınar Ağacıydım" başlıklı öyküde 6 deyim, 8 ikileme, 4 kalıplaşmış ifade yer almış, atasözü yer almamıştır. Öykü türü metinlerde, 12 deyim, 12 ikileme, 9 kalıplaşmış ifade yer almış, atasözüne yer verilmemiştir. Şiir türü metinde 2 ikileme yer almış, deyim, atasözü ve kalıplaşmış ifade yer almamıştır. Öykü türü metinlerde toplam 33, şiir türü metinde 2 kalıplaşmış söz varlığı unsuru belirlenmiştir.

"Millî Mücadele ve Atatürk" temasında 1 metin öykü, 1 metin şiir ve 1 metin denemedir. “Bilmeyen Var Mı?” başlıklı öyküde 12 deyim, 4 ikileme, 3 kalıplaşmış ifade yer almış, atasözü ise yer almamıştır. "Mustafa Kemal'in Kağnısı" başlıklı şiirde 2 deyim ve 12 ikileme yer almış, atasözü ve kalıplaşmış ifade yer almamıştır. "15 Temmuz" başlıklı denemede 7 deyim, 1 kalıplaşmış ifade yer almış, atasözü ve ikileme yer almamıştır. Öykü türü metinde toplam 19, şiir türü metinde 14 ve deneme türü metinde 8 kalıplaşmış söz varlı̆̆ı unsuru belirlenmiştir.

"Erdemler" temasında 1 metin fabl, 1 metin tiyatro ve 1 metin öyküdür. "Güvercin" başıklı fablda 4 deyim, 1 ikileme, 2 kalıplaşmış ifade yer alıış, atasözü yer almamıştır. "Karagöz ve HacivatIncelik" başlıklı tiyatroda 5 deyim, 4 ikileme, 18 kalıplaşmış ifade yer almış, atasözü yer almamıştır. "Püf Noktası" başlıklı öyküde 5 deyim, 2 ikileme, 1 kalıplaşmış ifade yer almış, atasözü yer almamıştır. Tiyatro türü metinde toplam 27, öykü türü metinde 8 ve fabl türü metinde 7 kalıplaşmış söz varlığı unsuru belirlenmiştir.

"Bilim ve Teknoloji” temasında 2 metin makale, 1 metin biyografidir. "Uzayda Bir Gün” başlıklı makalede 4 deyim, 1 kalıplaşmış ifade yer almış, atasözü ve ikileme yer almamıştır. "Sarımsak Soslu Makarna" başlıklı makalede 8 deyim yer almış, atasözü, ikileme ve kalıplaşmış ifade yer almamıştır. "Bir Dâhiyle Konuşmak" başlıklı biyografide 6 deyim, 1 ikileme yer almış, atasözü ve kalıplaşmış ifade yer almamıştır. Makale türü metinlerde toplam 13, biyografi türü metinde 7 kalıplaşmış söz varlığı unsuru belirlenmiştir. 
"Milli Kültürümüz" temasında 1 metin şiir, 1 metin öykü ve 1 metin makaledir. "Anadolu Sevgisi" başlıklı şiirde hiçbir kalıplaşmış söz varlığı unsuru yer almamıştır. "Forsa" başıklı öyküde 9 deyim, 1 kalıplaşmış ifade yer almış, atasözü ve ikileme yer almamıştır. "Tamburi Cemil Bey Enstrümanları Anlatıyor" başlıklı makalede kalıplaşmış söz varlığı unsuru yer almamıştır. Öykü türü metinde toplam 10 kalıplaşmış söz varlığı unsuru belirlenmiş, şiir ve makale türü metinlerde kalıplaşmış söz varlığı unsuru belirlenememiştir.

"Okuma Kültürümüz" temasında 1 metin öykü ve 1 metin şiirdir. "Okuma Kitaplarım” başlıklı öyküde 4 deyim, 2 ikileme yer almış, atasözü ve kalıplaşmış ifade yer almamıştır. "Kitabın Serüveni" başlıklı şiirde deyim, atasözü ve kalıplaşmış ifade yer almamış, yalnızca 1 ikileme yer almıştır. Öykü türü metinde toplam 6, şiir türü metinde 1 kalıplaşmış söz varlığı unsuru belirlenmiştir.

"Sağlık ve Spor" temasında 1 metin makale, 1 metin afiş ve 1 metin şiirdir. "Anadolu'nun Cirit Oyunları" başlıklı makalede; 13 deyim, 2 ikileme, 2 kalıplaşmış ifade yer almış, atasözü ise yer almamıştır. "Sağlıklı Yaşıyorum" başlıklı afişte; 6 deyim yer almış, atasözü ikileme ve kalıplaşmış ifade yer almamıştır. "Cazgır" başlıklı şiirde; 2 ikileme, 5 kalıplaşmış ifade yer almış, atasözü ve deyim yer almamıştır. Makale türü metinde toplam 17, afiş türü metinde 6, şiir türü metinde 7 kalıplaşmış söz varlı̆̆ı unsuru belirlenmiştir.

"Doğa ve Evren" temasında 1 metin şiir, 1 metin deneme ve 1 metin öyküdür. "Yüksek Evde Oturanın Türküsü" başlıklı şiirde kalıplaşmış söz varlığı unsurları yer almamıştır. "Reçete" başlıklı denemede 6 deyim, 2 ikileme ve 2 kalıplaşmış ifade yer almış, atasözü yer almamıştır. "Kar Tanesinin Serüveni" başlıklı öyküde 6 deyim, 3 ikileme yer almış, atasözü ve kalıplaşmış ifade yer almamıştır. Deneme türü metinde toplam 10, öykü türü metinde 9 kalıplaşmış söz varlığı unsuru belirlenmiş, şiir türü metinde hiçbir kalıplaşmış söz varlığı unsuru belirlenememiştir.

Tablo 1. 5. Sınıf Türkçe Ders Kitabı'nda yer alan metin türleri ile kalıplaşmış söz varlığı ilişkisi

\begin{tabular}{|c|c|c|c|c|c|}
\hline $\begin{array}{r}\text { Metin Türü ve } \\
\text { Sayısı }\end{array}$ & Deyim & İkileme & Atasözü & Kalıplaşmış Ifade & Toplam \\
\hline Öykü (7) & 46 & 23 & & 10 & 79 \\
\hline Şiir (6) & 2 & 17 & & 5 & 24 \\
\hline Makale (4) & 24 & 2 & & 3 & 29 \\
\hline Deneme (2) & 13 & 2 & & 3 & 18 \\
\hline Tiyatro (1) & 5 & 3 & & 8 & 16 \\
\hline Fabl (1) & 4 & 1 & & 2 & 7 \\
\hline Biyografi (1) & 2 & 1 & & & 3 \\
\hline Afiş (1) & 5 & & & & 5 \\
\hline Toplam & 101 & 49 & & 31 & 181 \\
\hline
\end{tabular}

Tablo 1 incelendiğinde; ders kitabında yer alan metin türlerinin öykü, şiir, makale, deneme, tiyatro, fabl, biyografi ve afiş olduğu görülmektedir. Ders kitabında; 7 öykü, 6 şiir, 4 makale, 2 deneme, 1 tiyatro, 1 fabl ve 1 afiş olmak üzere toplam 23 metin yer almaktadır. En fazla kalıplaşmış söz varlığı 


\section{Ortaokul Türkçe Ders Kitaplarında Yer Alan Metin Türleri ile Kalıplaşmış Söz Varlığı iliş̧kisi}

unsurunun olduğu metin türü, öyküdür. Öykülerde; 46 deyim, 23 ikileme ve 10 kalıplaşmış ifade olmak üzere toplam 79 kalıplaşmış söz varlığı unsuru belirlenmiştir. Öykülerde en fazla belirlenen kalıplaşmış söz varlığı unsuru, deyim ve hiç belirlenemeyen kalıplaşmış söz varlığı unsuru, atasözüdür. Atasözü, metinlerin hiçbirisinde belirlenememiştir. Ders kitabında, 181 kalıplaşmış söz varlığı unsuru belirlenmiştir.

5. Sınıf Türkçe Ders Kitabı'nda öykü türü metinlerle kalıplaşmış söz varlığı unsurları arasında yoğun bir ilişki belirlenmiştir. Metinlerde atasözüne hiç yer verilmemesi, bir eksiklik olarak değerlendirilmektedir.

\section{Sınıf Türkçe Ders Kitabı'nda Yer Alan Metin Türleri ve Kalıplaşmış Söz Varlığı Unsurları}

"Okuma Kültürü" temasında 2 metin öykü, 1 metin şiirdir. "Bu da Benim Öyküm” başlıklı öyküde 3 deyim ve 1 ikileme yer almış, atasözü ve kalıplaşmış ifade yer almamıştır. "Arıyorum" başlıklı şiirde 5 deyim, 1 ikileme, 2 kalıplaşmış ifade yer almış, atasözü ise yer almamıştır. "Canım Kitaplığım" başıklı öyküde 8 deyim, 3 ikileme, 2 kalıplaşmış ifade yer almış, atasözü yer almamıştır. Öykü türü metinlerde toplam 17, şiir türü metinde 8 kalıplaşmış söz varlığı unsuru belirlenmiştir.

"Millî Mücadele ve Atatürk" temasında 1 metin öykü, 1 metin anı ve 1 metin haber yazısıdır. "Türk Askerinin Cesareti" başıkı öyküde 5 deyim, 2 ikileme yer almış, atasözü ve kalıplaşmış ifade yer almamıştır. "Yaşlı Nine" başlıklı anıda 10 deyim, 1 ikileme, 4 kalıplaşmış ifade yer almış, atasözü yer almamıştır. "15 Temmuz" başlıklı haber yazısında 5 deyim, 4 kalıplaşmış ifade yer almış, atasözü ve ikileme yer almamıştır. Anı türü metinde toplam 15, haber yazısı türünde 9 , öykü türü metinde 7 kalıplaşmış söz varlığı unsuru belirlenmiştir.

"Bilim ve Teknoloji" temasında 2 metin makale ve 1 metin söyleşidir. "Aziz Sancar" başlıklı makalede 16 deyim, 4 kalıplaşmış ifade yer almış, ikileme ve atasözü yer almamıştır. "Insanlar Zamanı Eskiden Nasıl Ölçerdi?" başlıklı söyleşide 4 deyim, 2 ikileme yer almış, kalıplaşmış ifade ve atasözü yer almamıştır. "Teknoloji Bağımlılığı" başıklı makalede 2 deyim, 4 kalıplaşmış ifade yer almış, atasözü ve ikileme ise yer almamıştır. Makale türü metinlerde toplam 26, söyleşi türü metinde 6 kalıplaşmış söz varlığı unsuru belirlenmiştir. Bu bulgular ışığında söyleşi türü metinler, kalıplaşmış söz varlığı öğretimi için yeterli görülmemektedir. Makale türü metinler ise atasözü dışında kalıplaşmış söz varlığı öğretimi için kullanılabilmektedir.

"Erdemler" temasında 2 metin öykü ve 1 metin şiirdir. "Vermek Çoğalmaktır" başlıklı öyküde 10 deyim, 1 ikileme, 8 kalıplaşmış ifade yer almış, atasözü yer almamıştır. "Sevgi Diyen Çağlar Aşar" başlıklı şiirde 3 deyim, 1 kalıplaşmış ifade yer almış, atasözü ve ikileme yer almamıştır. "Gümüş Kanat" başlıklı öyküde 9 deyim, 4 ikileme, 4 kalıplaşmış ifade yer almış, atasözü yer almamıştır. Öykü türü metinlerde toplam 36, şiir türü metinde 15 kalıplaşmış söz varlığı unsuru belirlenmiştir. 
"Doğa ve Evren" temasında 2 metin makale ve 1 metin gezi yazısıdır. "Merak Ettiklerimiz" başlıklı makalede 2 deyim, 3 ikileme ve 2 kalıplaşmış ifade yer almış, atasözü ise yer almamıştır. "Afyon" başlıklı gezi yazısında 8 deyim, 2 ikileme, 4 kalıplaşmış ifade yer almış, atasözü ise yer almamıştır. "Su Kirliliği" başlıklı makalede 6 deyim 1 ikileme yer almış atasözü ve kalıplaşmış ifade yer almamıştır. Makale türü metinlerde toplam 14, gezi yazısı türünde 14 kalıplaşmış söz varlığı unsuru belirlenmiştir.

"Milli Kültürümüz" temasında 2 metin şiir ve 1 metin öyküdür. "Anadolu" başlıklı şiirde 2 deyim, 2 ikileme ve 2 kalıplaşmış ifade yer almış, atasözü ise yer almamıştır. "Tarhananın Öyküsü" başlıklı öyküde 1 deyim, 2 ikileme yer almış, atasözü ve kalıplaşmış ifade yer almamıştır. "Ana Dili” başlıklı şiirde 1 deyim, 2 ikileme, 2 kalıplaşmış ifade yer almış, atasözü ise yer almamıştır. Şiir türü metinlerde toplam 11, öykü türü metinde 3 kalıplaşmış söz varlığı unsuru belirlenmiştir.

"Sağılık ve Spor" temasında 1 metin deneme, 1 metin öykü ve 1 metin broşürdür. "Bisiklet Zamanı" başlıklı denemede 1 deyim, 1 kalıplaşmış ifade yer almış, atasözü ve ikileme yer almamıştır. "Yemek, İ̧mek ve Sindirmek" başıkılı öyküde 4 deyim, 1 ikileme yer almış, atasözü ve kalıplaşmış ifade yer almamıştır. "Obezite Hakkında 10 Soru 10 Cevap" başlıklı broşürde 1 deyim yer almış, atasözü, ikileme ve kalıplaşmış ifade yer almamıştır. Öykü türü metinde toplam 5 , deneme türü metinde 2 , broşür türü metinde 1 kalıplaşmış söz varlığı unsuru belirlenmiştir.

"Birey ve Toplum" temasında 1 metin tiyatro, 1 metin öykü ve 1 metin söyleşidir. "Evet Efendim" başlıklı tiyatroda 5 deyim, 7 ikileme, 4 kalıplaşmış ifade yer almış, atasözü yer almamıştır. "Sen de Bir İyilik Yap" başıkı öyküde 10 deyim, 4 ikileme, 5 kalıplaşmış ifade yer almış, atasözü yer almamıştır. "Dostluğa Dair" başlıklı söyleşide 4 deyim, yer almış, atasözü, ikileme ve kalıplaşmış ifade yer almamıştır. Öykü türü metinde toplam 19, tiyatro türü metinde 16 , söyleşi türü metinde 4 kalıplaşmış söz varlığı unsuru belirlenmiştir.

Tablo 2. 6. Sınıf Türkçe Ders Kitabı'nda yer alan metin türleri ile kalıplaşmış söz varlığı ilişkisi

\begin{tabular}{rccccc}
\hline $\begin{array}{r}\text { Metin Türü ve } \\
\text { Sayısı }\end{array}$ & Deyim & ikileme & Atasözü & Kalıplaşmış ifade & Toplam \\
\hline Öykü (8) & 49 & 17 & 16 & 82 \\
Şiir (4) & 11 & 5 & 6 & 22 \\
Makale (4) & 25 & 2 & 10 & 37 \\
Söyleşi (2) & 8 & 1 & & 9 \\
Deneme (1) & 1 & & 4 & 2 \\
Tiyatro (1) & 4 & 2 & 4 & 10 \\
Haber Yazısı (1) & 5 & & 4 & 9 \\
Anı (1) & 10 & 1 & 4 & 15 \\
Gezi Yazısı (1) & 8 & 2 & & 1 \\
Broşür (1) & 1 & & 49 & 201 \\
\hline Toplam & 122 & 30 & & 4 \\
\hline
\end{tabular}

Tablo 2 incelendiğinde; ders kitabında yer alan metin türlerinin öykü, şiir, makale, söyleşi, deneme, tiyatro, haber yazısı, anı, gezi yazısı ve broşür olduğu görülmektedir. Ders kitabında; 8 öykü, 4 şiir, 4 makale, 2 söyleşi, 1 deneme, 1 tiyatro, 1 haber yazısı, 1 gezi yazısı ve 1 broşür olmak üzere 


\section{Ortaokul Türkçe Ders Kitaplarında Yer Alan Metin Türleri ile Kalıplaşmış Söz Varlığı iliş̧kisi}

toplam 24 metin yer almaktadır. En fazla kalıplaşmış söz varlığı unsurunun olduğu metin türü, öyküdür. Öykülerde; 49 deyim, 17 ikileme ve 16 kalıplaşmış ifade olmak üzere toplam 82 kalıplaşmış söz varlığı unsuru belirlenmiştir. Öykülerde en fazla belirlenen kalıplaşmış söz varlığı unsuru, deyim ve belirlenemeyen kalıplaşmış söz varlığı unsuru, atasözüdür. Atasözü, metinlerin hiçbirisinde belirlenememiştir. Ders kitabında, 201 kalıplaşmış söz varlığı unsuru belirlenmiştir.

6. Sınıf Türkçe Ders Kitabı'nda öykü türü metinlerle kalıplaşmış söz varlığı unsurları arasında yoğun bir ilişki belirlenmiştir. Metinlerde atasözüne hiç yer verilmemesi, bir eksiklik olarak değerlendirilmektedir.

\section{Sınıf Türkçe Ders Kitabı'nda Yer Alan Metin Türleri ve Kalıplaşmış Söz Varlığı Unsurları}

"Erdemler" temasında 1 metin masal, 1 metin roman ve 1 metin tiyatrodur. "Arıların IIlhamı" başıklı masalda 7 deyim, 1 ikileme, 3 kalıplaşmış ifade yer almış, atasözü yer almamıştır. "Munise" başıklı romanda 11 deyim, 5 ikileme, 1 kalıplaşmış ifade yer almış, atasözü yer almamıştır. "Dostluk" başıklı tiyatroda 9 deyim, 3 kalıplaşmış ifade yer almış, atasözü ve ikileme yer almamıştır. Roman türü metinde toplam 17, tiyatro türü metinde 12 , masal türü metinde 11 kalıplaşmış söz varlığı unsuru belirlenmiştir.

"Millî Mücadele ve Atatürk" temasında 2 metin anı ve 1 metin şiirdir. "Vatan Destanı" başlıkı şiirde 1 deyim ve 1 kalıplaşmış ifade yer almış, atasözü ve ikileme yer almamıştır. "Ordular Ilk Hedefiniz" başlıklı anıda 4 deyim, 5 ikileme, 2 kalıplaşmış ifade yer almış, atasözü yer almamıştır. "Öğretmeninizden Af dileyeceksiniz" başlıklı anıda 11 deyim yer almış, atasözü, ikileme ve kalıplaşmış ifade yer almamıştır. Anı türü metinlerde toplam 22, şiir türü metinde 2 kalıplaşmış söz varlığı unsuru belirlenmiştir.

"Kişisel Gelişim" temasında 1 metin biyografi, 1 metin otobiyografi ve 1 metin denemedir. "Barış Manço" başlıklı biyografide; 4 deyim, 1 kalıplaşmış ifade yer almış, atasözü ve ikileme yer almamıştır. "Sol Ayağım" başlıklı otobiyografide; atasözü, ikileme ve kalıplaşmış ifade yer almamış, yalnızca 2 deyim yer almıştır. "Insanlarla Geçinme Sanatı" başlıklı denemede; 11 deyim yer almış, atasözü, ikileme ve kalıplaşmış ifade yer almamıştır. Deneme türü metinde toplam 11, biyografi türü metinde 5, otobiyografi türü metinde 2 kalıplaşmış söz varlığı unsuru belirlenmiştir.

"Milli Kültürümüz" temasında 1 metin makale, 1 metin tiyatro ve 1 metin şiirdir. "Türk Mutfak Kültüründe Kahve" başlıklı makalede; 4 deyim, 2 atasözü, 4 ikileme yer almış, kalıplaşmış ifade yer almamıştır. "Ben Mimar Sinan" başlıklı tiyatroda; 13 deyim, 1 ikileme,1 kalıplaşmış ifade yer almış, atasözü yer almamıştır. "Türkiye'm, Ana Yurdum, Sebebim, Çarem” başlıklı şiirde; 2 deyim, 5 ikileme yer almış, atasözü ve kalıplaşmış ifade yer almamıştır. Tiyatro türü metinde toplam 15, makale türü metinde 10, şiir türü metinde 7 kalıplaşmış söz varlığı unsuru belirlenmiştir. 
"Bilim ve Teknoloji" temasında 1 metin çizgi roman, 1 metin roman ve 1 metin makaledir. "Piri Reis" başlıklı çizgi romanda; 4 deyim, 3 ikileme, 4 kalıplaşmış ifade yer almış, atasözü yer almamıştır. “2100’deki Yaşamdan Bir Gün” başlıklı romanda; 9 deyim, 2 ikileme yer almış, atasözü ve kalıplaşmış ifade yer almamıştır. "Yeni Dünya" başlıklı makalede; 5 deyim, 2 ikileme yer almış, atasözü ve kalıplaşmış ifade yer almamıştır. Çizgi roman türü metinde 11 , roman türü metinde 11 , makale türü metinde 7 kalıplaşmış söz varlığı unsuru belirlenmiştir.

"Okuma Kültürü" temasında 2 metin deneme ve 1 metin öyküdür. "Okumak Deyince" başlıklı denemede 10 deyim, 1 ikileme yer almış, atasözü ve kalıplaşmış ifade yer almamıştır. "Divanu Lugati't Türk'ün Bulunuş Hikâyesi” başlıklı öyküde 5 deyim ve 1 kalıplaşmış ifade yer almış, atasözü ve ikileme yer almamıştır. "Okumak Ayrıcalıktır Herkes Okuyamaz" başlıklı denemede 5 deyim, 3 ikileme, 2 kalıplaşmış ifade yer almış, atasözü yer almamıştır. Deneme türü metinlerde toplam 21, öykü türü metinde 6 kalıplaşmış söz varlığı unsuru belirlenmiştir.

"Doğa ve Evren" temasında 1 metin günlük, 1 metin şiir ve 1 metin gezi yazısıdır. "ilk Kar" başıkıı günlükte 2 deyim, 10 ikileme yer almış, atasözü ve kalıplaşmış ifade yer almamıştır. "Bu Sabah Hava Berrak" başlıklı şiirde deyim, atasözü ve kalıplaşmış ifade yer almamış, yalnızca 2 ikileme yer almıştır. "Lavanta Kokulu Köy” başlıklı gezi yazısında 3 deyim, 1 ikileme yer almış, atasözü ve kalıplaşmış ifade yer almamıştır. Günlük türü metinde toplam 12, gezi yazısı türü metinde 4, şiir türü metinde 2 kalıplaşmış söz varlığı unsuru belirlenmiştir.

"Zaman ve Mekân" temasında 2 metin şiir ve 1 metin gezi yazısıdır. "istanbul” başlıklı şiirde 1 deyim, 4 ikileme yer almış, atasözü ve kalıplaşmış ifade yer almamıştır. "Akşehir'de Bir Fil” başlıklı şiirde, 6 deyim, 1 ikileme, 3 kalıplaşmış ifade yer almış, atasözü yer almamıştır. "Moena Türk Köyü" başlıklı gezi yazısında 2 deyim, 1 ikileme, 2 kalıplaşmış ifade yer almış, atasözü yer almamıştır. Şiir türü metinlerde toplam 15, gezi yazısı türü metinde 5 kalıplaşmış söz varlığı unsuru belirlenmiştir.

Tablo 3. 7. Sınıf Türkçe Ders Kitabı'nda yer alan metin türleri ile kalıplaşmış söz varlığı ilişkisi

\begin{tabular}{rccccc}
\hline $\begin{array}{r}\text { Metin Türü ve } \\
\text { Sayısı }\end{array}$ & Deyim & ikileme & Atasözü & Kalıplaşmış ifade & Toplam \\
\hline Şiir (5) & 10 & 12 & & 4 & 26 \\
Deneme (3) & 26 & 4 & & 2 & 32 \\
Roman (2) & 19 & 6 & & 4 & 26 \\
Tiyatro (2) & 22 & 1 & & 2 & 27 \\
Anı (2) & 15 & 5 & & 1 & 22 \\
Gezi Yazısı (2) & 4 & 2 & 2 & 3 & 17 \\
Makale (2) & 9 & 6 & & 1 & 11 \\
Masal (1) & 7 & 1 & & 4 & 2 \\
Biyografi (1) & 4 & & & 11 \\
Otobiyografi (1) & 2 & & & & 6 \\
Çizgi Roman (1) & 4 & 3 & & 23 & 204 \\
Öykü (1) & 5 & & & & \\
Günlük (1) & 2 & 10 & & & \\
\hline Toplam & 129 & 50 & 2 & & \\
\hline
\end{tabular}




\section{Ortaokul Türkçe Ders Kitaplarında Yer Alan Metin Türleri ile Kalıplaşmış Söz Varlığı iliş̧kisi}

Tablo 3 incelendiğinde; ders Kitabında yer alan metin türlerinin şiir, deneme, roman, tiyatro, anı, gezi yazısı, makale, masal, biyografi, otobiyografi, çizgi roman, öykü ve günlük olduğu görülmektedir. Ders kitabında; 5 şiir, 3 deneme, 2 roman, 2 tiyatro, 2 anı, 2 gezi yazısı, 2 makale, 1 masal, 1 biyografi, 1 otobiyografi, 1 çizgi roman, 1 öykü ve 1 günlük olmak üzere toplam 24 metin yer almaktadır. En fazla kalıplaşmış söz varlığı unsurunun olduğu metin türü, denemedir. Denemelerde 26 deyim, 4 ikileme ve 2 kalıplaşmış ifade olmak üzere toplam 32 kalıplaşmış söz varlığı unsuru belirlenmiştir. Denemelerde en fazla belirlenen kalıplaşmış söz varlığı unsuru, deyim ve hiç yer belirlenemeyen kalıplaşmış söz varlığı unsuru, atasözüdür. Atasözü, makale dışında metin türlerinin hiçbirisinde belirlenememiştir. Ders kitabında, 204 kalıplaşmış söz varlığı unsuru belirlenmiştir.

7. Sınıf Türkçe Ders Kitabı'nda deneme türü metinlerle kalıplaşmış söz varlığı unsurları arasında bir ilişki belirlenmiştir. Metinlerde, 2 atasözü belirlenmiştir. Metinlerde atasözüne çok az yer verilmesi, bir eksiklik olarak değerlendirilmektedir.

\section{Sınıf Türkçe Ders Kitabı'nda Yer Alan Metin Türleri ve Kalıplaşmış Söz Varlığı Unsurları}

"Kişisel Gelişim" temasında 1 metin söyleşi, 1 metin öykü ve 1 metin masaldır. "Benlik Üzerine" başlıklı söyleşide 7 deyim yer almış, atasözü, ikileme ve kalıplaşmış ifade yer almamıştır. "Martı" başlıklı öyküde 14 deyim, 4 ikileme yer almış, atasözü ve kalıplaşmış ifade yer almamıştır. "Acele Karar Vermeyin" başlıklı masalda 9 deyim, 1 ikileme, 1 kalıplaşmış ifade yer almış, atasözü yer almamıştır. Öykü türü metinde toplam 18, masal türü metinde 11, söyleşi türü metinde 7 kalıplaşmış söz varlığı unsuru belirlenmiştir.

"Millî Mücadele ve Atatürk" temasında 1 metin tiyatro, 1 metin şiir ve 1 metin denemedir. "Vatan Yahut Silistre" başlıklı tiyatroda 9 deyim, 4 ikileme, 6 kalıplaşmış ifade yer almış, atasözü yer almamıştır. "O Geliyor" başlıklı şiirde 1 deyim, 3 ikileme yer almış, atasözü ve kalıplaşmış ifade yer almamıştır. "istiklal Madalyası” başlıklı denemede 8 deyim, 1 ikileme yer almış, atasözü ve kalıplaşmış ifade yer almamıştır. Tiyatro türü metinde toplam 19, deneme türü metinde 9 , şiir türü metinde 4 kalıplaşmış söz varlığı unsuru belirlenmiştir.

"Birey ve Toplum" temasında 2 metin deneme ve 1 metin şiirdir. "Faydalı Bir İş Görmek Zevki" başıkılı denemede 13 deyim, 8 ikileme yer almış, atasözü ve kalıplaşmış ifade yer almamıştır. "Gurbet" başlıklı şiirde deyim, atasözü ikileme ve kalıplaşmış ifade yer almamıştır. "Türkçenin Zenginliği” başlıklı denemede 2 deyim, 2 ikileme yer almış, atasözü yer almamıştır. Deneme türü metinlerde toplam 25 kalıplaşmış söz varlığı unsuru belirlenmiş, şiir türü metinde hiçbir kalıplaşmış söz varlı̆̆ı unsuru belirlenememiştir.

"Sanat" temasında 2 metin makale ve 1 metin şiirdir. "Sanat" başlıklı şiirde 4 deyim, 1 ikileme, 1 kalıplaşmış ifade yer almış, atasözü yer almamıştır. "Mikro Minyatür" başlıklı makalede 10 deyim,1 ikileme yer almış, atasözü ve kalıplaşmış ifade yer almamıştır. "Selimiye Camii" başıklı makalede 5 
deyim, 2 ikileme yer almış, atasözü ve kalıplaşmış ifade yer almamıştır. Makale türü metinlerde toplam 18, şiir türü metinde 6 kalıplaşmış söz varlığı unsuru belirlenmiştir.

"Milli Kültürümüz" temasında 1 metin şiir, 1 metin efsane ve 1 metin destandır. "Anadolu Uygarlıkları" başlıklı şiirde deyim, atasözü ve kalıplaşmış ifade yer almamış, yalnızca 1 ikileme yer almıştır. "Burada Dur" başlıklı efsanede 4 deyim, 2 ikileme yer almış, atasözü ve kalıplaşmış ifade yer almamıştır. "Ergenekon Destanı” başlıklı destanda 17 deyim, 1 ikileme yer almış, atasözü ve kalıplaşmış ifade yer almamıştır. Destan türü metinde 18, efsane türü metinde 6, şiir türü metinde 1 kalıplaşmış söz varlığı unsuru belirlenmiştir.

"Zaman ve Mekân" temasında 1 metin söyleşi, 1 metin şiir ve 1 metin öyküdür. "Kalbin Sesi" başlıklı söyleşide 5 deyim, 3 ikileme yer almış, atasözü ve kalıplaşmış ifade yer almamıştır. "Geçen Zaman" başlıklı şiirde hiçbir kalıplaşmış söz varlığı unsuru yer almamıştır. "Değirmende Döner Taşım" başlıklı öyküde 12 deyim, 6 ikileme, 7 kalıplaşmış ifade yer almış, atasözü yer almamıştır. Öykü türü metinde 25, söyleşi türü metinde 8 kalıplaşmış söz varlığı unsuru belirlenmiş, şiir türü metinde hiçbir kalıplaşmış söz varlığı unsuru belirlenememiştir.

"Erdemler" temasında 1 metin deneme, 1 metin şiir ve 1 metin öyküdür. "Yunus Emre'nin Mezarları" başlıklı denemede 5 deyim, 6 ikileme, 4 kalıplaşmış ifade yer almış, atasözü yer almamıştır. "Gülü İncitme Gönül” başlıklı şiirde atasözü, ikileme ve kalıplaşmış ifade yer almamış, yalnızca 1 deyim yer almıştır. "Emine Teyze'nin Çilek Reçeli" başlıklı öyküde 9 deyim, 10 ikileme yer almış, atasözü ve kalıplaşmış ifade yer almamıştır. Öykü türü metinde toplam 19, deneme türü metinde 15 , şiir türü metinde 1 kalıplaşmış söz varlığı unsuru belirlenmiştir.

"Hak ve Özgürlükler" temasında 1 metin öykü, 1 metin biyografi ve 1 metin şiirdir. "Bilge Adamın Yolu" başlıklı öyküde 6 deyim, 3 ikileme yer almış, atasözü ve kalıplaşmış ifade yer almamıştır. "Aliya İzzet Begoviç ve Özgürlük Mücadelesi” başlıklı biyografide 5 deyim, 1 ikileme ve 1 kalıplaşmış ifade yer almış, atasözü yer almamıştır. "Özgürlük" başlıklı şiirde deyim, atasözü ve kalıplaşmış ifade yer almamış, yalnızca 1 ikileme yer almıştır. Öykü türü metinde toplam 9, biyografi türü metinde 7, şiir türü metinde 1 kalıplaşmış söz varlığı unsuru belirlenmiştir.

Tablo 4. 8. Sınıf Türkçe Ders Kitabı'nda yer alan metin türleri ile kalıplaşmış söz varlığı ilişkisi

\begin{tabular}{|c|c|c|c|c|c|}
\hline $\begin{array}{r}\text { Metin Türü ve } \\
\text { Sayısı }\end{array}$ & Deyim & İkileme & Atasözü & Kalıplaşmış Ifade & Toplam \\
\hline Şiir (7) & 6 & 6 & & 1 & 13 \\
\hline Öykü (4) & 37 & 21 & & 6 & 64 \\
\hline Deneme (4) & 23 & 16 & & 2 & 41 \\
\hline Makale (2) & 14 & 3 & & & 17 \\
\hline Söyleşi (2) & 8 & 3 & & & 11 \\
\hline Masal (1) & 7 & 1 & & 1 & 9 \\
\hline Tiyatro (1) & 5 & 2 & & 5 & 12 \\
\hline Efsane (1) & 4 & 2 & & & 6 \\
\hline Destan (1) & 14 & 1 & & & 15 \\
\hline Biyografi (1) & 5 & 1 & & 1 & 7 \\
\hline
\end{tabular}


Toplam 123

56

16

195

Tablo 4 incelendiğinde; ders kitabında yer alan metin türlerinin şiir, öykü, deneme, makale, söyleşi, masal, tiyatro, efsane, destan ve biyografi olduğu görülmektedir. Ders kitabında; 7 şiir, 4 öykü, 4 deneme, 2 makale, 2 söyleşi, 1 masal, 1 tiyatro, 1 efsane, 1 destan ve 1 biyografi olmak üzere toplam 24 metin yer almaktadır. En fazla kalıplaşmış söz varlığı unsurunun olduğu metin türü, öyküdür. Öykülerde; 37 deyim, 21 ikileme ve 6 kalıplaşmış ifade olmak üzere toplam 64 kalıplaşmış söz varlığı unsuru belirlenmiştir. Öykülerde en fazla belirlenen kalıplaşmış söz varlığı unsuru, deyim ve belirlenemeyen kalıplaşmış söz varlığı unsuru, atasözüdür. Atasözü, metinlerin hiçbirisinde belirlenememiştir. Ders kitabında, 195 kalıplaşmış söz varlığı unsuru belirlenmiştir.

8. Sınıf Türkçe Ders Kitabı'nda öykü türü metinlerle kalıplaşmış söz varlığı unsurları arasında yoğun bir ilişki belirlenmiştir. Metinlerde atasözüne hiç yer verilmemesi, bir eksiklik olarak değerlendirilmektedir.

\section{Tartışma, Sonuç ve Öneriler}

Araştırma, Türkçe Dersi Öğretim Programı (2018) temelinde hazırlanan ortaokul Türkçe ders kitaplarında yer alan metin türleri ile kalıplaşmış söz varlığı unsurları arasındaki ilişkiyi belirlemek amacıyla gerçekleştirilmiştir. Araştırma amacı doğrultusunda ders kitaplarındaki metinler, türlerine göre sınıflandırılmış ve bu metinlerde yer alan kalıplaşmış söz varlığı unsurları belirlenmiştir. Metin türleri ile kalıplaşmış söz varlığı unsurları ilişkilendirilmiştir.

Alanyazın incelendiğinde önceki Türkçe dersi öğretim programlarına göre hazırlanmış Türkçe ders kitaplarındaki söz varlığı unsurlarına ilişkin çalışmaların yapıldığı görülmektedir (Akın, 2018; Apaydın 2010; Turhan, 2010; Uludağ, 2010). Yapılan çalışmalar, metinlerdeki söz varlığı unsurlarını belirlemeye yöneliktir. Çalışmalarda, metin türleri ile kalıplaşmış söz varlığı ilişkisine yönelik herhangi bir bulguya rastlanmamıştır. Bu araştırma, güncel olması ve metin türleri ile kalıplaşmış söz varlığı ilişkisini belirlemesi yönüyle alanyazındaki çalışmalardan ayrılmaktadır. Alanyazındaki çalışmalarla yapılan söz varlığı unsuru sayısına yönelik karşılaştırmalarda, araştırmaların sınırlılıklarının göz önünde bulundurulması gerekmektedir. Bu araştırmada, serbest okuma metinleri ile dinleme/izleme metinleri kapsam dışında tutulmuştur.

5. Sınıf Türkçe Ders Kitabı'nda, 181 kalıplaşmış söz varlığı unsuru belirlenmiştir. Akın (2018), 2017-2018 eğitim öğretim yılında MEB tarafından okutulmasına karar verilen 5. Sınıf Türkçe Ders Kitabı üzerinde yaptığı araştırmada, 394 kalıplaşmış söz varlığı unsuru belirlemiştir. 5. Sınıf Türkçe Ders Kitabı’nda kalıplaşmış söz varlığı unsuru sayısının önceki ders kitabına göre azaldığı görülmektedir. 6. Sınıf Türkçe Ders Kitabı'nda, 201 kalıplaşmış söz varlığı unsuru belirlenmiştir. Apaydın (2010), 20092010 eğitim öğretim yılında okutulan 6. Sınıf Türkçe Ders Kitabı (MEB Yayınları) üzerinde yaptığı 
araştırmada, 147 kalıplaşmış söz varlığı unsuru belirlemiştir. 6. Sınıf Türkçe Ders Kitabı'nda kalıplaşmış söz varlığı unsuru sayısının önceki ders kitabına göre arttığı görülmektedir. 7. Sınıf Türkçe Ders Kitabı'nda, 204 kalıplaşmış söz varlığı unsuru belirlenmiştir. Uludağ (2010), 2009-2010 eğitim öğretim yılında 7. Sınıf Türkçe Ders Kitabı (MEB Yayınları) üzerinde yaptığı araştırmada, 269 kalıplaşmış söz varlığı unsuru belirlemiştir. 6. Sınıf Türkçe Ders Kitabı'nda kalıplaşmış söz varlığı unsuru sayısının önceki ders kitabına göre azaldığı görülmektedir. 8. Sınıf Türkçe Ders Kitabı’nda, 195 kalıplaşmış söz varlığı unsuru belirlenmiştir. Turhan (2010), 2009-2010 eğitim öğretim yılında 8. Sınıf Türkçe Ders Kitabı (MEB Yayınları) üzerinde yaptığı araştırmada, 262 kalıplaşmış söz varlığı unsuru belirlemiştir. 8. Sınıf Türkçe Ders Kitabı'nda kalıplaşmış söz varlığı unsuru sayısının önceki ders kitabına göre azaldığı görülmektedir.

Araştırma ile ulaşılan sonuçlar aşağıda sunulmuştur:

5. Sınıf Türkçe Ders Kitabı'nda yer alan metin türleri; öykü, şiir, makale, deneme, tiyatro, fabl, biyografi ve afiştir. Ders kitabında; 7 öykü, 6 şiir, 4 makale, 2 deneme, 1 tiyatro, 1 fabl ve 1 afiş olmak üzere toplam 23 metin yer almaktadır. En fazla kalıplaşmış söz varlığı unsurunun olduğu metin türü, öyküdür. Öykülerde; 46 deyim, 23 ikileme ve 10 kalıplaşmış ifade olmak üzere toplam 79 kalıplaşmış söz varlığı unsuru belirlenmiştir. Öykülerde en fazla belirlenen kalıplaşmış söz varlığı unsuru, deyim ve hiç belirlenemeyen kalıplaşmış söz varlığı unsuru, atasözüdür. Atasözü, metinlerin hiçbirisinde belirlenememiştir. Bu durum bir eksiklik olarak değerlendirilebilir. Ders kitabında, 181 kalıplaşmış söz varlığı unsuruna yer verilmiş ve öykü türü metinlerle kalıplaşmış söz varlığı unsurları arasında yoğun bir ilişki belirlenmiştir.

6. Sınıf Türkçe Ders Kitabı'nda yer alan metin türleri; öykü, şiir, makale, söyleşi, deneme, tiyatro, haber yazısı, anı, gezi yazısı ve broşürdür. Ders kitabında; 8 öykü, 4 şiir, 4 makale, 2 söyleşi, 1 deneme, 1 tiyatro, 1 haber yazısı, 1 gezi yazısı ve 1 broşür olmak üzere toplam 24 metin yer almaktadır. En fazla kalıplaşmış söz varlığı unsurunun olduğu metin türü, öyküdür. Öykülerde; 49 deyim, 17 ikileme ve 16 kalıplaşmış ifade olmak üzere toplam 82 kalıplaşmış söz varlığı unsuru belirlenmiştir. Öykülerde en fazla belirlenen kalıplaşmış söz varlığı unsuru, deyim ve belirlenemeyen kalıplaşmış söz varlığı unsuru, atasözüdür. Atasözü, metinlerin hiçbirisinde belirlenememiştir. Bu durum bir eksiklik olarak değerlendirilebilir. Ders kitabında, 201 kalıplaşmış söz varlığı unsuruna yer verilmiş ve öykü türü metinlerle kalıplaşmış söz varlığı unsurları arasında yoğun bir ilişki belirlenmiştir.

7. Sınıf Türkçe Ders Kitabı'nda yer alan metin türleri; şiir, deneme, roman, tiyatro, anı, gezi yazısı, makale, masal, biyografi, otobiyografi, çizgi roman, öykü ve günlüktür. Ders kitabında; 5 şiir, 3 deneme, 2 roman, 2 tiyatro, 2 anı, 2 gezi yazısı, 2 makale, 1 masal, 1 biyografi, 1 otobiyografi, 1 çizgi roman, 1 öykü ve 1 günlük olmak üzere toplam 24 metin yer almaktadır. En fazla kalıplaşmış söz varlığı unsurunun olduğu metin türü, denemedir. Denemelerde 26 deyim, 4 ikileme ve 2 kalıplaşmış ifade 


\section{Ortaokul Türkçe Ders Kitaplarında Yer Alan Metin Türleri ile Kalıplaşmış Söz Varlığı ílişkisi}

olmak üzere toplam 32 kalıplaşmış söz varlığı unsuru belirlenmiştir. Denemelerde en fazla belirlenen kalıplaşmış söz varlığı unsuru, deyim ve belirlenemeyen kalıplaşmış söz varlığı unsuru, atasözüdür. Atasözü, makale dışında metin türlerinin hiçbirisinde belirlenememiştir. Bu durum bir eksiklik olarak değerlendirilebilir. Ders kitabında, 204 kalıplaşmış söz varlığı unsuruna yer verilmiş ve deneme türü metinlerle kalıplaşmış söz varlığı unsurları arasında bir ilişki belirlenmiştir.

8. Sınıf Türkçe Ders Kitabı'nda yer alan metin türleri; şiir, öykü, deneme, makale, söyleşi, masal, tiyatro, efsane, destan ve biyografidir. Ders kitabında; 7 şiir, 4 öykü, 4 deneme, 2 makale, 2 söyleşi, 1 masal, 1 tiyatro, 1 efsane, 1 destan ve 1 biyografi olmak üzere toplam 24 metin yer almaktadır. En fazla kalıplaşmış söz varlığı unsurunun olduğu metin türü, öyküdür. Öykülerde; 37 deyim, 21 ikileme ve 6 kalıplaşmış ifade olmak üzere toplam 64 kalıplaşmış söz varlığı unsuru belirlenmiştir. Öykülerde en fazla belirlenen kalıplaşmış söz varlığı unsuru, deyim ve belirlenemeyen kalıplaşmış söz varlığı unsuru, atasözüdür. Bu durum bir eksiklik olarak değerlendirilebilir. Ders kitabında, 195 kalıplaşmış söz varlığı unsuruna yer verilmiş ve öykü türü metinlerle kalıplaşmış söz varlığı unsurları arasında yoğun bir ilişki belirlenmiştir.

Ortaokul Türkçe ders Kitaplarında en fazla yer verilen metin türleri, şiir ve öyküdür. Kitaplarda 22 şiir ve 20 öykü metnine yer verilmiştir. Öykülerde 231, şiirlerde 85 söz varlığı unsuru belirlenmiştir. Öykülerde 137 deyim, 61 ikileme ve 33 kalıplaşmış ifade; şiirlerde 29 deyim, 40 ikileme ve 16 kalıplaşmış ifade belirlenmiştir. Deyim, ikileme ve kalıplaşmış ifadelere en fazla yer verilen metin türü öyküdür. Atasözü; 5, 6 ve 8. Sınıf Türkçe ders kitaplarında belirlenememiş; 7. Sınıf Türkçe Ders Kitabı'nda makale türü metinlerde 2 tane belirlenebilmiştir. Ders kitaplarında en fazla belirlenen kalıplaşmış söz varlığı unsuru deyim, en az belirlenen ise atasözü olmuştur. Atasözüne çok az yer verilmesi, ortaokul Türkçe ders Kitaplarının bir eksikliği olarak değerlendirilmektedir. Genel olarak ders kitaplarında öykü türü metinlerle kalıplaşmış söz varlığı unsuru arasında yoğun bir ilişki belirlenmiştir.

Araştırma süreci ve sonuçlarından hareketle ortaokul Türkçe ders kitaplarında yer alan metin türlerinin daha özenle seçilmesi ve hazırlanması, kalıplaşmış söz varlığı unsurları bakımından metinlerde yeterliliğin sağlanması, metin türlerindeki sınıflamaların doğru yapılması ve atasözüne daha fazla yer verilmesi önerileri geliştirilmiştir.

\section{Kaynaklar}

Akın, K. (2018). Ortaokul 5. sınıf Türkçe ders kitabında yer alan okuma metinlerinin söz varlığı üzerine bir değerlendirme. Social Sciences Studies Journal, 4(22), 3695-3706.

Aksan, D. (2004). Türkçenin söz varlığı. Ankara: Engin Yayınevi.

Apaydın, N. (2010). 6. sınıf Türkçe ders kitaplarının söz varlığı açısından incelenmesi (Yayımlanmamış Yüksek Lisans Tezi). Marmara Üniversitesi Eğitim Bilimleri Enstitüsü, İstanbul.

Demir, C. (2016). Türkçe eğitim öğretim programları ve kişisel söz varlı̆ı. Milli Eğitim Dergisi, 210, 141-161. 
Esgin, A. (2016). Yurt dışında yapılmış söz varlığı çalışmalarının yöntemleri üzerine bir değerlendirme. Milli Eğitim Dergisi, 210, 55-83.

Göçer, A. (2009). Türkçe eğitiminde öğrencilerin söz varlığını geliştirme etkinlikleri ve sözlük kullanımı. Turkish Studies International Periodical For the Languages, Literature and History of Turkish or Turkic, 4(4), 1025-1055.

Gökdayı, H. (2008). Türkçede kalıp sözler. Bilig, 44, 89-110.

Karadüz, A. (2009). Sözlük, sözcük anlamı ve öğrenme üzerine. Turkish Studies International Periodical for the Languages, Literature and History of Turkish or Turkic, 4(4), 636-649.

Karasar, N. (2012). Bilimsel araştırma yöntemi. 24. Baskı. Ankara: Nobel Akademik Yayıncılık.

Karatay, H. (2016). 6-8. sınıf öğrencilerinin mecazlı dili anlama düzeyleri. Milli Eğitim Dergisi, 210, 265-285.

MEB (2018). Ortaokul ve imam hatip ortaokulu 5. sınıf Türkçe ders kitabı. Ankara: Talim ve Terbiye Kurulu Başkanlığı.

MEB (2018). Ortaokul ve imam hatip ortaokulu 6. sınıf Türkçe ders kitabı. Ankara: Talim ve Terbiye Kurulu Başkanlığı.

MEB (2018). Ortaokul ve imam hatip ortaokulu 7. sınıf Türkçe ders kitabı. Ankara: Talim ve Terbiye Kurulu Başkanlığı.

MEB (2018). Ortaokul ve imam hatip ortaokulu 8. sınıf Türkçe ders kitabı. Ankara: Talim ve Terbiye Kurulu Başkanlı̆̆ı.

MEB (2018). Türkçe dersi öğretim programı. Ankara: Talim ve Terbiye Kurulu Başkanlığı.

Merriam, S. B. (2013). Qualitative research a guide to desing and implementation. Selahattin Turan (Çev. Ed.). 3. Basımdan Çeviri. Ankara: Nobel Yayınları.

Tağa, T. (2016). Kelime öğretiminde hedef kelimelerin belirlenmesi. Milli Eğitim Dergisi, 210, 163-177.

TDK (2005). Büyük Türkçe Sözlük. Ankara: Türk Dil Kurumu Yayınları.

Turhan, H. (2010). 8. sınıf Türkçe ders kitaplarındaki metinlerin söz varlığı açısından incelenmesi (Yayımlanmamış Yüksek Lisans Tezi). Marmara Üniversitesi Eğitim Bilimleri Enstitüsü, İstanbul.

Uludağ, Ç. (2010). 7. sınıf Türkçe ders kitaplarının söz varlığı açısından incelenmesi (Yayımlanmamış Yüksek Lisans Tezi). Marmara Üniversitesi Eğitim Bilimleri Enstitüsü, İstanbul.

Yıldırım, A., \& Şimşek, H. (2013). Sosyal bilimlerde nitel araştırma yöntemleri. 9. Baskı. Ankara: Seçkin Yayınları.

\section{Extended Abstract \\ Introduction}

The vocabulary of a language has a core that retains its value in the presence of social interactions from the depths of human thoughts and emotions (Karadüz, 2009). This core is very dominant in the Turkish language. As a result, Turkish is a language with rich vocabulary that is equipped with broad expressive possibilities. The development of vocabulary is largely linked to Turkish lessons as acquiring an effective vocabulary is included in the aims of these lessons. In this context, the texts studied in Turkish lessons have an important function in transferring the rich vocabulary content of Turkish to students. The aim of the present study was to determine the relationship between text types and the elements of formulaic expression used in these texts in secondary school Turkish language arts textbooks prepared based on the Turkish Language Arts Curriculum (2018). In this study, the texts included in the Turkish language arts textbooks were classified according to type and the types of formulaic expression used in the text types were determined. This study is important for the elements of vocabulary, one of the basic outcomes targeted in Turkish lessons, to reach a certain maturity in the texts.

\section{Method}

A qualitative research method was employed in this study. The data collected for the study comprised of 95 texts (documents) included in 5th, 6th, 7th and 8th grade Turkish textbooks (MoNE Publications) prepared based on the Turkish curriculum (2018). Listening/watching, free reading and visual texts (excluding those containing writing) were not included in the scope of the data. The block type texts determined in the Turkish 
Language Arts Curriculum were evaluated within the scope of document types in consideration with content. The collection of data was completed with a documentary review. The texts included in the textbooks were classified according to written expression types by 3 field experts and 5 Turkish teachers. When determining the text types, classification was based on the text types included in the Turkish Language Arts Curriculum (2018). Elements of formulaic expression were determined according to the outcomes included in the curriculum (idioms, repetition, proverbs and formulaic expressions). The study findings were reached by associating text types with the presence of formulaic expression elements. The research data was revealed with descriptive analysis and the results are presented as tables.

\section{Result and Discussion}

When the relevant literature was investigated, it was found that there were studies performed on the elements of vocabulary in Turkish language arts textbooks prepared according to previous the Turkish language arts Curriculums (Akın, 2018; Apaydın 2010; Turhan, 2010; Uludağ, 2010). These studies focused on determining the elements of vocabulary in the texts. However, the screening of the relevant literature did not reveal any studies conducted on determining the relationship of text types with formulaic expressions. The results of the present study and the recommendations developed are presented below.

The text types most commonly included in secondary school Turkish language arts textbooks were poetry and stories. The books included a total of 22 poems and 20 story texts. It was determined that the stories included 231 expression elements while the poems included 85. In addition, the stories included 137 idioms, 61 repetitions and 33 formulaic expressions, while the poems included 29 idioms, 40 repetitions and 16 formulaic expressions. The text type including the most idioms, repetitions and formulaic expression was stories. Proverbs were not determined in the $5^{\text {th }}, 6^{\text {th }}$ and $8^{\text {th }}$ grade Turkish language textbooks, and only 2 were determined in the article text type in the 7th grade Turkish Language Arts Textbooks. The most commonly determined formulaic expression element in the textbooks was idioms, while proverbs were identified the least. The lack of proverbs was assessed as a deficiency of secondary school Turkish language arts textbooks.

Based on the results given above, various recommendations were developed for more care to be taken during the selection and preparation of text types to be included in secondary school Turkish language arts textbooks, thus ensuring sufficiency in terms of formulaic expression elements, accurate classification of text types, and greater inclusion of proverbs. 